\title{
IMPLEMENTASI FUNGSI KEPOLISIAN SEBAGAI PELINDUNG PENGAYOM DAN PELAYAN MASYARAKAT DALAM MEWUJUDKAN KETERTIBAN DAN KEAMANAN MASYARAKAT KECEMATAN LIUKANG KALMAS KABUPATEN PANGKEP
}

\author{
The Implementation of Police Functions as the Public Patron, Protector and Servant in Actualizing \\ Public Order and Security in Liukang Kalmas District of Pangkep Regency
}

\author{
I Made Untung Sunantara ${ }^{1}$, Imran Ismail ${ }^{2}$, Andi Rasyid Pananrangi ${ }^{2}$ \\ ${ }^{1}$ Kepolisian Resort Pangkep \\ ${ }^{2}$ Program Studi Ilmu Administrasi Negara Program Pascasarjana Universitas Bosowa
}

Email: madeuntung78@gmail.com

Diterima: 15 Februari 2020

Dipublikasikan: 05 Juni 2020

\begin{abstract}
ABSTRAK
Penelitian ini bertujuan untuk mengkaji, menganalis dan menginterpertasi tentang implementasi fungsi kepolisian sebagai pelindung pengayom, pelayan masyarakat Kecamatan Liukang Kalmas Kabupaten Pangkep yang di laksanakan oleh pihak kepolisian di Polsek Liukang Kalmas menyakut hak-hak sipil serta keamanan dan ketertiban masyarakat sesuai dengan fungsi kepolisian sudah berjalan sesuai dengan aturan dan undang-undang yang berlaku. Penelitian ini bersifat deskriptif analisis dengan mengunakan pendekatan kualitatif. Hasil penelitian menunjukan bahwa, implementasi fungsi kepolisian sebagai pelindung pengayom, pelayan masyarakat Kecamatan Liukang Kalmas kabupaten Pangkep, sudah cukup maksimal dengan keadaan Kecamatan yang berada dalam sebuah pulau hal ini disebabkan karena jarak satu pulau ke pulau cukup jauh, kurangnya personil Polsek Liukang Kalmas di tambah lagi tidak adanya Transportasi umum laut yang tidak dengan gelombang dengan gelombang laut yang ekstrim. Tetapi kelebihan masyarakat kepulauan masih timgginya adat tolenransi, satu rumpun
\end{abstract}

Kata Kunci: Fungsi Kepolisian, Masyarakat, Ketertiban, Keamanan, Liukang Kalmas, Pangkep

\begin{abstract}
This study aims to examine, analyze and interpret: the implementation of the function of the police as the public patron, protector, and servant in the District of Liukang Kalmas, Pangkep Regency carried out by the police in the Liukang Kalmas Police Station, regarding civil rights as well as public security and order in accordance with the functions of the police that are running based on the rules and laws. This research is a descriptive analysis using a qualitative approach where the data is obtained from a number of informants: Deputy Chief of Police in Pangkep, Police Members of Samapta Section, Police Members of the Intelligence Unit, the Police Members of Investigation Section, Police Members of Traffic Section, Community/Community Leaders. The results showed that the implementation of the police function as the public patron, protector dan servant in the Liukang Kalmas District, Pangkep Regency, was already maximal with the condition where the districts within the islands are quite far, the lack of police officers and aso the absence of public transportation within the islands with extreme ocean waves. However, the strength of the island community is the high value of traditional custom and tolerance in one family.
\end{abstract}

Keywords: Function, Police, Society, Services, Protection, Liukang Kalmas, Pangkep

\section{PENDAHULUAN}

Negara Indonesia adalah Negara yang berdasarkan hukum, hal ini tercantum dalam Pasal 1 ayat (3) UndangUndang Dasar Negara Republik Indonesia Tahun 1945 dimana hukum adalah peraturan yang berupa norma dan sanksi yang dibuat dengan tujuan untuk mengatur tingkah laku manusia, menjaga ketertiban, keadilan, mencegah terjadinya kekacauan dalam kehidupan bermasyarakatPelaksanaan fungsi kepolisian terhadap ketertiban dan keamanan masyarakat di Kecamatan Liungkang Kalmas Kabupaten Pangkep Pola penegakkan hukum dipengaruhi oleh tingkat perkembangan masyarakat, tempat hukum tersebut berlaku atau diberlakukan. Alat-alat Negara yaitu Polisi, Jaksa dan hakim yang merupakan pengemban tugas khusus menjaga tegaknya hukum dan keadilan, aparat penegak hukum ini di dalam bertindak juga berdasarkan hukum sesuaidengan kewarganegaraannya masing-masing yang telah ditentukan secara tegas dalam undang-undang.

Pelaksanaan tugas Polri yang mencakup tugas pelayanan masyarakat, pengayoman dan perlindungan selain tugasnya sebagai alat negara penegak hukum membuka wawasan yang lebih luas ke arah pemberdayaan masyarakat, namun tetap menitikberatkan kepada orientasi profesi dengan pertimbangan rasional dan obyektif. Perspektif Teori. Teori Implementasi. Konsep implementasi semakinmarak dibicarakan seiring denganbanyaknya pakar yang memberikan kontribusi 
pemikiran tentang implementasi kebijakan sebagai salah satu tahap dari proses kebijakan. Tahap implementasi kebijakan pada posisi yang berbeda, namun pada prinsipnya setiap kebijakan publik selalu ditindak lanjuti dengan implementasi kebijakan.

Soekanto (2005), menyatakan bahwa salah satu fungsi hukum baik sebagai kaidah maupun sebagai sikap tindak atau perilaku teratur adalah membimbing perilaku manusia. Masalah pengaruh hukum tidak hanya terbatas pada timbulnya ketaatan atau kepatuhan pada hukum, tapi mencakup efek total dari hukum terhadap sikap tindak atau prilaku baik yang bersifat positif maupu negatif. Pembaharuan Undang-undang Kepolisian Indonesia, UU No. 2 Tahun 2002 dimaksudkan untuk lebih memantapkan kedudukan dan peran Polri sebagai fungsi pemerintahan meliputi pemeliharaan keamanan dan ketertiban masyarakat, penegakan hukum, perlindungan dan pengayoman dan pelayanan kepada masyarakat yang menjunjung tinggi hak asasi manusia, harus bebas dari pengaruh kekuasaan pihak manapun, yakni yang dilaksanakan secara merdeka terlepas dari pengaruh kekuasaan pemerintah dan pengaruh kekuasaan lainnya.

Agustiono, (2006) menyatakan implementasi merupakan suatu proses yang dinamis, dimana pelaksana kebijakan melakukan suatu aktivitas atau kegiatan, sehingga pada akhirnya akan mendapatkan suatu hasil yang sesuai dengan tujuan atau sasaran kebijakan itu sendiri Teori Polisi. Polisi sebagai salah satu alat / institusi penegak hukum memiliki tugas dan kewajiban yang sangat fundamental. Profesi Kepolisian memiliki ruang lingkup pekerjaan yang sangat luas dan mengandung resiko tinggi, terutama dalam rangka mewujudkan situasi keamanan dan ketertiban masyarakat serta penegakan hukum. Menurut Nawawi (2005) dan Nirwana et al., (2019) bahwa Polri dalam menjalankan tugasnya berperan ganda baik sebagai penegak hukum maupun sebagai pekerja sosial sosial worker pada aspek sosial dan kemasyarakatan (pelayanan dan pengabdian). Prilaku masyarakat dan penegak hukum menurut Soerjono Soekanto, (2004) berpendapat bahwa Salah satu fungsi hukum baik sebagai kaidah maupun sebagai sikap tindak atau perilaku teratur adalah membimbing perilaku manusia.

Kewenangan umum untuk memberikan bantuan pengamanan juga dapat dimanfaatkan dalam kegiatan instansi lain serta kegiatan masyarakat pada umumnya. Namun demikian pengguman kewenangan ini hanya atas permintaan instansi yang berkepentingan atau atas permintaan masyarakat. Berdasar pada pandangan hukum, menurut Amiruddin (2010), menjelaskan bahwa dalam masyarakat modern mempunyai solidaritas sosial organis, selanjutnya juga menjelaskan bahwa hukum yang terdapat dalam masyarakat modern merupakan hukum restruktif yaitu hukum berfungsi untuk mengembalikan keadaan seperti semula dan untuk membentuk kembali hubungan yang sukar atau kacau kearah atau menjadi normal. Jadi masyarakat modern merupakan yang sudah tidak terpaku pada adat-istiadat dan cenderung mempunyai solidaritas organis karena mereka saling membutuhkan serta hukum yang ada bersifat restrukti.Teori Pelayanan.Pelayanan publik yang prima merupakan tanda dari kesadaran baru dari pemerintah atas tanggung jawab utama dalam mengelolah pemerintahan dan memenuhi segala kebutuhan masyarakat. Menurut Ratminto \& Winarsi (2005) dalam Donni Juni Priansa (2017) pelayanan adalah suatu aktivitas atau serangkaian aktivitas yang bersifat tidak kasat mata yang terjadi akibat adanya interaksi antara pelanggan dengan pegawai atau hal-hal lain yang disediakan oleh perusahaan pemberi pelayanan yang dimaksudkan untuk memecahkan permasalahan pelangganTeori Pelayanan Publik. Undang-Undang No. 25 Tahun 2009 tentang Pelayanan Publik mendefinisikan pelayanan publik adalah kegiatan atau rangkaian kegiatan dalam rangka pemenuhan kebutuhan pelayanan sesuai dengan peraturan perundang-undangan bagi setiap warga negara dan penduduk atas barang, jasa, dan/atau pelayanan administratif yang disediakan oleh penyelenggara pelayanan publik. Menurut Lewis \& Gilman (2005) mendefinisikan Pelayanan publik sebagai kepercayaan publik. Warga negara berharap pelayanan publik dapat melayani dengan kejujuran dan pengelolaan sumber penghasilan secara tepat, dan dapat dipertanggungjawabkan kepada publik. Pelayanan publik yang adil dan dapat dipertanggungjawabkan menghasilkan kepercayaan publik. Dibutuhkan etika pelayanan publik sebagai pilar dan kepercayaan publik sebagai dasar untuk mewujudkan pemerintah yang baik.

Polri sebagai agen penegak hukum dan pembina keamanan dan ketertiban masyarakat. Konsepsi tugas, fungsi dan peran Polri yang bersumber dari landasan yang masih relevan namun masih perlu diorintasikan dengan perkembangan masyarakat. Polri dengan keberadaannya membawa empat peran strategis, yakniperlindungan masyarakat, penegakan hukum, pencegahan pelanggaran hukum dan pembinaan keamanan dan ketertiban masyarakat.

Sebagaimana diatur'dalam ketentuan UU No. 2 Tahun 2002 tentang Polri secara gamblang dirumuskan bahwa tugas pokok Polri adalah penegak hukum, pelindung, pengayom dan pembimbing masayarakat erutama dalam rangka kepatuhan dan ketaatan pada hukum yang berlaku. Pembaharuan Undang-undang Kepolisian Indonesia, UU No. 2 Tahun 2002 dimaksudkan untuk lebih memantapkan kedudukan dan peran Polri sebagai fungsi pemerintahan meliputi pemeliharaan keamanan dan ketertiban masyarakat, penegakkan hukum, perlindungan dan pengayoman dan pelayanan kepada masyarakat yang menjunjung tinggi hak asasi manusia (Pasal 4, Undang-Undang Nomor 2 Tahun 2002), harus bebas dari pengaruh kekuasaan pihak manapun, yakni yang dilaksanakan secara merdeka terlepas dari pengaruh kekuasaan pemerintah dan pengaruh kekuasaan lainnya (Riwanto \& Gumbira, 2017). 
Penelitian ini bertujuan untuk mengkaji, menganalis dan menginterpertasi mengenai implementasi fungsi kepolisian sebagai pelindung pengayom, pelayan masyarakat Kecamatan Liukang Kalmas Kabupaten Pangkep yang di laksanakan oleh pihak kepolisian di Polsek Liukang Kalmas menyakut hak-hak sipil serta keamanan dan ketertiban masyarakat sesuai dengan fungsi kepolisian sudah berjalan sesuai dengan aturan dan undang-undang yang berlaku

\section{METODE PENELITIAN}

Jenis metode yang dipakai dalam penelitian ini yaitu metode pendekatan kualitatif dimana paradigma, proses, metode, dan tujuanya berbeda, penelitian kualitatif memiliki model desain yang berbeda dengan penelitian kuantitatif. Penelitian ini di lakukan di Kantor Polsek Liukang Kalmas dalam wilayah kerja Polres Kabupaten Pangkep Polda Sulawesi Selatan. Fokus penelitian ini pelaksanaan fungsi kepolisian sebagai pelindung, pengayom dan pelayan masyarakat terhadap ketertiban dan keamanan Kecamata Liungka Kalmas Kabupaten Pangkep.

Informan yang di butuhkan oleh peneliti adalah Waka Polres Pangkep Anggota Kepolisian bagian Samapta Anggota kepolisian bagian Intelkam Anggota kepolisian bagian Reserse Anggota kepolisian bagian Lantas Masyarakat/tokoh masyarakat Jumlah yang di butuhkan yaitu 9 orang.

Teknik pengumpulan data yakni wawancara, penelitian menggunakan metode kualitatif sehingga pertanyaan yang digunakan dalam wawancara merupakan pertanyaan terbuka agar informan bisa menjawab dengan lebih leluasa/bebas. Dokumentasi untuk mencari data penelitian kualitatif yang akan dilakukan berupa arsip dan/atau format dari dokumen. Observasi dilakukan peneliti dengan mengamati dan berpartisipasi langsung dengan informan yang sedang diteliti.

Teknik analisis data yang digunakan dalam penelitian kualitatif adalah data atau temuan yang dapat dinyatakan valid bila tidak ada perbedaan antara yang dilaporkan peneliti dengan apa yang terjadi di lokasi penelitian.

\section{HASIL DAN PEMBAHASAN}

Hasil penelitian menunjukkan bahwa peran Polri sangat dominan dilokasi penelitian, sebab organisasi ini mempunyai tugas melaksanakan di bidang reformasi birokrasi Polri sesuai dengan kebijakan Kapolri serta mempunyai fungsi dalam penyusunan dan pelaksanaan rencana strategis dan rencana kerja di bidang pelayanan pengayoman dan perlindungan kepada masyarakat. Salah satu fungsi pemerintahan dibidang keamanan adalah terpeliharannya ketertiban dan keamanan masyarakat, penegakan hukum, perlindungan, pengayoman, dan pelayanan masyarakat. Untuk mewujudkan hasil yang maksimal maka dibutuhkan kerjasama antara Polri dan masyarakat, sebagai satu kesatuan yang saling membutuhkan, Polri tidak akan dapat mewujudkan situasi aman dan tertib dalam suatu lingkungan tanpa adanya kesadaran dan partisipasi masyarakat itu sendiri.

Kurang cepatnya kehadiran Polri di tengah-tengah masyarakat dalam rangka melindungi keselamatan jiwa raga, harta benda, dan lingkungan hidup dari gangguan ketertiban dan bencana. Polri dalam kaitannya dengan Pemerintahan merupakan salah satu fungsi pemerintahan negara di bidang harkamtibmas, penegakan hukum, perlindungan, pengayoman, dan pelayanan kepada masyarakat untuk mewujudkan keamanan dalam negeri yang meliputi terpeliharanya keamanan dan ketertiban masyarakat, tegaknya hukum, terlaksanannya perlindungan, pengayoman, dan pelayanan kepada masyarakat, serta terbinanya ketentraman masyarakat dengan menjunjung tinggi hak azasi manusia.

Pelayan Pemerintah pada hakekatnya adalah pemerintah melayani masyarakat, bukan masyarakat yang melayani pemerintah. Pelayanan public yang profesional dapat terwujudkan bila adanya akuntabilitas dan respontabilitas pemberi layanan dalam hal ini aparatur pemerintah. Salah satu tugas pemerintah yang terpenting adalah memberikan pelayanan umum kepada masyarakatnya.

Masih adanya anggota Kepolisian yang ingin dilayani dalam pelaksanakan tugas Kepolisian, seharusnya anggota Polri yang harus memberikan pelayanan kepada masyarakat yang membutuhkan bantuan seperti mengurus SIM, membuat SKCK dan membuat laporan kejadian.

Faktor penghambat pelaksanaan tugas Kepolisian di Polsek Liukang Kalmas masih adanya anggota Kepolisian yang tidak sepenuh hati bertugas di Polsek Liukang Kalmas, sehingga anggota berupaya untuk pindah tugas dari Polsek Liukang Kalmas serta tidak peduli degan perubahan-perubahan yang terjadi di organisasi Kepolisian. Padahal Birokrasi Polri dimanapun bertugas harus dapat memberikan layanan publik yang lebih profesional, efektif, sederhana, transparan, terbuka, tepat waktu, responsif dan adaptif serta sekaligus dapat membangun kualitas manusia dalam arti meningkatkan kapasitas individu dan masyarakat secara aktif.

Integritas dan profesioanalisme aparat penegak hukum dalam hal ini penyidik maupun atasan penyidik selaku pejabat pengawas harus konsisten sehingga dalam proses penegakkan hukum tidak pandang bulu dan tetap lurus sesuai dengan isi materi dan petunjuk yang ada dalam perkara yang di tangani, jangan sampai perubahan perilaku yang ada di masyarakat, mempengaruhi proses penegakan hukum yang dapat merugikan salah satu pihak dan mencoreng nama Institusi Polri.

Faktor Hukum Itu Sendiri diwujudkan secara konstektual berupa perundang-undangan atau peraturan lainya yang disahkan oleh pejabat berwenang, merupakan pedoman bagi aparat penegak hokum dalam menjalankan wewenangnya, sehingga sekalipun tindakan dari aparat dengan upaya paksa dan disebut melanggar hak asasi 
manusia, namun jika peraturan perundang-undangan membenarkan perbuatan aparat penegak hukum maka perbuatan tersebut sah dan legal secara hukum. Adanya anggota Kepolisian dalam pelaksanakan tugas tidak berpedoman pada Standar Operasional Prosedur (SOP). Meningkatkan integritas aparat penegak hukum merupakan syarat mutlak yang harus dimiliki setiap orang khususnya aparat penegak hukum, sehingga dapat meningkatkan kualitas diri. Jika seseorang memiliki kualitas mental baik maka dengan mudah orang tersebut akan menerima apa yang dimiliki dan mampu mengoptimalkannya. Masih kurangnya personel yang mengikuti pendidikan kejuruan Kepolisian dan pendidikan umum setingkat Sarjana.

Faktor pendukung implementasi reformasi birokrasi Polri di Polsek Liukang Kalmas adalah sebagaian besar anggota berkeinginan untuk menjadikan citra Polri yang positif dimata masyarakat dapat terjaga dengan baik. Masih banyak anggota Polsek Liukang Kalmas yang bertugas benar-benar memberikan pelayanan yang terbaik dan profesional kepada masyarakat Liukang Kalmas. Demikian juga sebagaian besar masyarakat Liukang Kalmas merasa senang dengan kehadiran anggota Polsek Liukang Kalmas di tegah-tengah masyarakat dalam menjalankan tugasnya sebagai penegak hukum dan pelayan masyarakat.

Dorongan politik Fungsi pemerintahan yang dimiliki oleh Kepolisian dalam hal keamanan dan ketertiban masyarakat, yang teknisnya melalui perizinan, pengesahan, persetujuan, pengawasan atau kontrol, penyelidikan dan penuntutan. Selain fungsi pemerintahan, dalam undang-undang Kepolisian juga terdapat fungsi penegakan hukum dan fungsi perlindungan yang diamanatkan pada Kepolisian. Fungsi penegakkan hukum sebagai kosekuensi Negara hukum, sehingga memerlukan suatu lembaga yang dibebani tugas untuk menegakkan hukum yang ada. Sedang fungsi perlindungan, pengayoman, dan pelayanan kepada masyarakat, sematamata untuk mewujudkan ketentraman dan menjaga dari segala gangguan dan ancamanyang datangnya dari masyarakat sendiri. Pada dasarnya segala yang mengganggu ketentraman yang dirasakan oleh masyarakat berhak dituntut oleh masyarakat sendiri dalam penyelenggaraan keamanan, ketertiban, dan ketenteraman bagi masyarakat. Malasnya masyarakat melaporkan suatu kejadian pelanggaran hukum kepada anggota Polri, karena masyarakat Liukang Kalmas masih dalam satu rumpun sehingga penyelesaiannya secara kekeluargaan. Tekanan Ekonomi dan Peningkatan Efisiensi Tekanan ekonomi dan peningkatan efesiensi menjadi salah satu faktor dilaksanakanya inovasi Smile Police untuk meningkatkan efesiensi terhadap masyarakat dalam menerima pelayanan dari Kepolisian. Karena jika dilihat dari sisi tekanan tingkat ekonomi dan efisiensi anggaran bagi instansi maka tidak mungkin karena untuk menciptakan suatu inovasi berbasis IT sudah pasti mengeluarkan biaya yang lebih besar. Fasilitas yang berbasis IT belum ada yang memadai, mengingat kurangnya fasilitas yang dibangun oleh pemerintah atau swasta khususnya di daerah Liukang Kalmas.Teknologi.novasi Smile Police sudah didukung dengan teknologi hardware dan software yang lengkap Operator harus khusus operator, tidak merangkap fungsi, agar tidak terkesan serabutan dan menjadi tidak maksimal. Kondisi saat ini adalah anggota yang dijadikan khusus operator yaitu polwan dan Polisi siaga ditambah polwan juga yang diperbantukan. Masih adanya anggota Polri yang menjalankan tugas lain selain tugas pokoknya sehingga menjadi tidak optimal dalam pekerjaan atau tidak fokus dalam menjalankan tugas pokoknya.

\section{KESIMPULAN}

Peranan Kepolisian Daerah Pangkep khususnya Polsek Liukang Kalmas dalam menanggulangi tindak pidana sebagai aparat dipercayakan oleh negara untuk menjalankan fungsi penegakan hukum, pemeliharaan keamanan dan ketertiban masyarakat, serta pelindung, pengayom, dan pelayan masyarakat, berkewajiban untuk mencegah dan menanggulangi tindak pidana yang terjadi. Upaya untuk mengatasi hambatan dalam menjalankan fungsi Kepolisian Polsek Liukang Kalmas melakukan berbagai upaya, melakukan sosialisasi dan penyuluhan kepada masyarakat terkait dengan kesadaran hukum masyarakat. Diharapkan dengan adanya sosialisasi dan penyuluhan tersebut dapat menumbuhkan kesadaran hukum dan kepercayaan masyarakat kepada pihak Kepolisian, sehingga masyarakat bisa bekerjasama dengan aparat Kepolisian dalam menanggulangi kejahatan

Untuk mengoptimalkan tugas patroli Kepolisian Polsek Liukang Kalmas dalam rangka menjaga keamanan dan ketertiban masyarakat, agar Polres Pangkep melengkapi sarana dan prasarana transportasi laut yang memadai mengingat wilayah Polsek Liukang Kalmas tediri dari kepulauan yang jaraknya berjauhan dengan gelombang laut yang cukup tinggi.

\section{DAFTAR PUSTAKA}

Agustiono, L, (2006), Dasar-Dasar Kebijakan Publik, Bandung: Alfabeta

Amiruddin, 2010, Pengantar Metode Penelitian Hukum, Jakarta: PT Raja Grafindo Persada.

Barda Nawawi. (2005) Bunga Rampai Kebijakan Hukum Pidana. Bandung; PT. Citra Aditya Bakti..

Donni Juni Priansa. (2017). Manajemen Pelayanan Prima, Focus Pada Organisasi Publik dan peningkatan Kualitas Aparatur. Bandung: Alfabeta.

Lewis, Carol W., and Stuart C. Gilman. (2005). The Ethics Challenge in PublicService: A ProblemSolving Guide. Market Street, San Fransisco: JosseyBass.

Nirwana, N., Nonci, N., \& Maidin, R. (2019). Budaya Kerja Kepolisian Dalam Sistem Pelayanan Surat Izin Mengemudi (Sim) Pada Kantor Kepolisian Resort 
Kabupaten Bone Provinsi Sulawesi Selatan. Jurnal Paradigma Administrasi Negara, 1(1), 21-26

Ratminto \& Atik Septi Winarsih. (2005). Manajemen Pelayanan. Jakarta: Pustaka Pelajar Press.

Riwanto, Agus., \& Gumbira,Seno Wibowo.(2017) Politik Hukum Penguatan Fungsi Negara Untuk Kesejahteraan Rakyat (Studi Tentang Konsep Dan Praktik Negara Kesejahteraan Menurut Uud 1945)/Legal Policy Of Strengthening State Functions For People's Welfare (Concepts And Practices Study Of Welfare State Based On The 1945 Constitution). Jurnal Hukum dan Peradilan, Vol.6, (No.3),p.2528.

Soerjono Soekanto (2005), Faktor-faktor yang Mempengaruhi Penegakan Hukum. Jakarta: Rajawali.

Soerjono Soekanto, (2004) Faktor-faktor yang Mempengaruhi Penegakan Hukum. Cet Kelima. Jakarta: Rajawali..

Undang-Undang Dasar Negara Republik Indonesia Tahun 1945.

Undang-Undang No. 25 Tahun 2009 tentang Pelayanan Publik. 